\title{
Corrigendum: The Risky Closed Economy: A Holistic, Longitudinal Approach to Studying Fear and Anxiety in Rodents
}

OPEN ACCESS

Approved by:

Frontiers Editorial Office,

Frontiers Media SA, Switzerland

*Correspondence:

Jeansok J. Kim

jeansokk@u.washington.edu

Specialty section:

This article was submitted to Emotion Regulation and Processing,

a section of the journal

Frontiers in Behavioral Neuroscience

Received: 22 March 2021 Accepted: 23 March 2021

Published: 09 April 2021

Citation:

Schuessler BP, Zambetti PR,

Fukuoka KM, Kim EJ and Kim JJ (2021) Corrigendum: The Risky

Closed Economy: A Holistic, Longitudinal Approach to Studying

Fear and Anxiety in Rodents.

Front. Behav. Neurosci. 15:684179.

doi: 10.3389/fnbeh.2021.684179

\section{Bryan P. Schuessler ${ }^{1}$, Peter R. Zambetti ${ }^{1}$, Kisho M. Fukuoka ${ }^{1}$, Eun Joo Kim ${ }^{1}$ and Jeansok J. Kim ${ }^{1,2 *}$ \\ ${ }^{1}$ Department of Psychology, University of Washington, Seattle, WA, United States, ${ }^{2}$ Program in Neuroscience, University of Washington, Seattle, WA, United States}

Keywords: fear, anxiety, decision-making, methods, ethology

\section{A Corrigendum on}

The Risky Closed Economy: A Holistic, Longitudinal Approach to Studying Fear and Anxiety in Rodents

by Schuessler, B. P., Zambetti, P. R., Fukuoka, K. M., Kim, E. J., and Kim, J. J. (2020). Front. Behav. Neurosci. 14:594568. doi: 10.3389/fnbeh.2020.594568

An author name was incorrectly spelled as Kisho M. Kukuoka. The correct spelling is Kisho M. Fukuoka.

The authors apologize for this error and state that this does not change the scientific conclusions of the article in any way. The original article has been updated.

Copyright $\odot 2021$ Schuessler, Zambetti, Fukuoka, Kim and Kim. This is an open-access article distributed under the terms of the Creative Commons Attribution License (CC BY). The use, distribution or reproduction in other forums is permitted, provided the original author(s) and the copyright owner(s) are credited and that the original publication in this journal is cited, in accordance with accepted academic practice. No use, distribution or reproduction is permitted which does not comply with these terms. 